\title{
MODELING OF AN ADVANCED HEAT EXCHANGE UNIT WITH MICROCHANNELS FOR A COMBINED PHOTOENERGY SYSTEM
}

Purpose. Mathematical modeling of the heat exchange unit main parameters for photoenergy system based on general models with forced circulation of heat transfer fluid. Methodology. To determine the coefficient of heat transfer at a given coolant temperature and surfaces temperature necessary to determine the temperature gradient in the wall of the heat exchanger. Temperature gradients can be determined by solving the equation of energy, which depends on the distribution of the flow rate in the flow. In general, a solution of convective heat transfer fluid to flow along the plane comes to solution of the system of differential equations. Results. In the paper features of the selection of theoretical basis and mathematical modeling of thermal processes in the heat exchange unit for combination photoenergy system are presented. As a result of the simulation conducted we improve and develop high-efficiency heat exchange unit with microchannels. Testing of the proposed unit proved its high efficiency through the implementation of turbulent flow of coolant with heat transfer coefficient at $18 \mathrm{~kW} /\left(\mathrm{m}^{2} \cdot \mathrm{K}\right)$. Analytical testing of the heat exchanger allowed showing that heat exchanger unit provides a stable operating temperature at less than $50{ }^{\circ} \mathrm{C}$ with the coolant flow rate is less than $0.3 \mathrm{~m} / \mathrm{s}$. Originality. Novelty of the proposed heat exchanger is in the optimal design of microchannels to improve the heat transfer coefficient. Practical value. The use of this heat exchanger will improve the quality and uniformity of cooling solar panels and reduce energy costs for circulation of fluid. References 12, figures 4. Key words: heat exchanger unit, coolant, solar panels, combined photoenergy system.

В работе рассматриваются особенности подбора теоретических основ и математическое моделирование тепловых процессов в теплообменном блоке для комбинированной фотоэнергетической установки. По результатам моделирования проведено совершенствование $и$ разработка высокоэффективного теплообменного блока с микроканалами. Апробация предложенного блока подтверждает его высокую эффективность за сцет реализации турбулентного режима протекания теплоносителя. Использование такого теплообменника позволить повысить качество и равномерность охлаждения солнечных батарей и уменьшить затраты энергии на циркуляцию жидкости. Библ. 12, рис. 4.

Ключевые слова: теплообменный блок, теплоноситель, солнечная батарея, комбинированная фотоэнергетическая установка.

Introduction. Global energy market trends and the associated increase in the consumption of natural energy resources clearly show the need to find additional sources of energy that could compensate for the lack of available resources, and ideally - completely replace them. As the experience of the USA, Japan, Germany, shows one of the ways to solve this problem associated with the conversion of solar energy into electricity using semiconductor photovoltaic cells (solar cells - SC).

The most common type of SC is devices based on the structure of mono- and polycrystalline silicon thickness of $200 \mu \mathrm{m}$. The main problem of their widespread use is the high price of electricity they produce, due to high material and energy intensity of the process of manufacture. To reduce the cost of SC promising is the use of systems operating under concentrated solar radiation. The use of mirrors allows hundreds of times lower cost of SC. However, the use of silicon SC based on traditional designs with concentrated solar radiation reduces the efficiency of the order $[1,2]$. At the same time, the use of silicon multijunction SC with vertical diode cells with increasing intensity of solar radiation demonstrates the increased efficiency $[3,4]$.

Developed earlier [5] photoenergy plant based on silicon multijunction SCs with vertical diode cells or SC based on gallium arsenide, which has a positioning and control system, thus increasing the amount of light energy that comes to the surface power plant has many advantages. Such a photoenergy plant will produce not only electricity but also heat water. But along with this, there were severely difficulties in uniform cooling of installed SC that are needed to specifically address [6-8]. The conventional notation $[9,10]$ is used in this article.

The goal of the work is mathematical modeling of the main parameters of the heat exchange unit for photoenergy plant based on general models of heat transfer at forced circulation of fluid.

1. Investigation technique. In accordance with the general standard requirements for photoenergy plants for industrial equipment, the output voltage of the solar battery (SB) must not exceed $U_{N M}=48 \mathrm{~V}$; load current $I_{N M}=10.4 \mathrm{~A}$; electric power that SB transits to the load $P_{N M}$ up to $500 \mathrm{~W}$. Hence, at the $S_{S B} \approx 100 \mathrm{~cm}^{2}$ specific electrical power $P_{N M}$ can be calculated, which is given to the load by $1 \mathrm{~cm}^{2}$ of such SB and which is equal to $5 \mathrm{~W} / \mathrm{cm}^{2}$. However, along with this, at the maximum possible efficiency of SC, for example based on gallium arsenide, at $30 \%$, to provide the necessary parameters, to the SB surface light with power density of at least $16.7 \mathrm{~W} / \mathrm{cm}^{2}$ has come. So the power of $11.7 \mathrm{~W} / \mathrm{cm}^{2}$ is excessive and will come to the SB and the heat exchanger in the form of heat, which will lead to significant and rapid overheating of SB.

The aperture area of the mirror system that concentrates, $S_{a} \approx 2.4 \mathrm{~m}^{2}$. At the solar radiation power $P_{s}=1000 \mathrm{~W} / \mathrm{m}^{2}$ the energy coming to this area $Q_{s}=2396 \mathrm{~W}$. By selecting better material for the mirrors, the proportion of energy supplied to the photodetector plate after accounting reflectance of mirrors $\left(r_{z}=0.95\right)$, and the processes of reflection and absorption system plate - glass, which takes into account absorptive capacity 
( $\left.\tau_{\alpha}\right)$ [9] we have $Q_{s 1}=r_{z} Q_{s}\left(\tau_{\alpha}\right)=1761 \mathrm{~W}$ (this corresponds to the effective concentration factor $K_{\text {eff }}=386$ ). After conversion of the part of this energy into electrical energy with efficiency $\eta=30 \%$, giving $Q_{s 2}=528 \mathrm{~W}$ of electrical energy, into thermal energy $Q_{s 3}=Q_{s 1}(1-\eta)=1233 \mathrm{~W}$ transfer.

To determine the coefficient of heat transfer at given temperature of the coolant and the surface temperature that flowed it is necessary to determine the temperature gradient in the wall of the heat exchanger. Temperature gradient can be determined by solving the equation of energy, which in turn depends on the distribution of the flow velocity in the considered flow region. In general terms, solving the problem of convective heat transfer fluid for fluid flow along the plane comes to solving the following system of differential equations (1) [9]

$$
\left\{\begin{array}{l}
\frac{1}{\rho} \frac{\partial \rho}{\partial \tau}+\frac{\partial w_{x}}{\partial x}+\frac{\partial w_{y}}{\partial y}=0 \\
\frac{\partial w_{x}}{\partial \tau}+w_{x} \frac{\partial w_{y}}{\partial x}+w_{y} \frac{\partial w_{x}}{\partial y}=\frac{\mu}{\rho}\left(\frac{\partial^{2} w_{x}}{\partial x^{2}}+\frac{\partial^{2} w_{x}}{\partial y^{2}}\right)-\frac{1}{\rho} \frac{\partial \rho}{\partial x}+g_{x} \\
\frac{\partial w_{y}}{\partial \tau}+w_{x} \frac{\partial w_{y}}{\partial x}+w_{y} \frac{\partial w_{y}}{\partial y}=\frac{\mu}{\rho}\left(\frac{\partial^{2} w_{y}}{\partial x^{2}}+\frac{\partial^{2} w_{y}}{\partial y^{2}}\right)-\frac{1}{\rho} \frac{\partial \rho}{\partial y}+g_{y} \\
\frac{\partial T}{\partial \tau}+w_{x} \frac{\partial T}{\partial x}+w_{y} \frac{\partial T}{\partial y}=\frac{\lambda}{\rho c_{p}}\left(\frac{\partial^{2} T}{\partial x^{2}}+\frac{\partial^{2} T}{\partial y^{2}}\right) \\
p=\rho R T
\end{array}\right.
$$

Such a system of equations in general defies analytic solution, therefore special cases are considered.

1.1. Heat transfer at the motion of fluid in direct smooth pipes. At moving liquids and gases in pipes and channels there are laminar $\left(R e_{f, d} \leq 2300\right)$, turbulent $\left(R e_{f, d} \geq 10^{4}\right)$ and the transition from laminar to turbulent $\left(2300<R e_{f, d}<10^{4}\right)$ regimes of fluid flow.

Definitive the parameters for calculating the Reynolds criterion: $T_{0}=T_{f}=0.5 \cdot\left(T_{f, \text { in }}+T_{f \text {,out }}\right)-$ the average temperature of the fluid in the; $R_{o}=d_{i n}-$ internal pipe diameter; $w_{0}=G /(\rho \cdot f)$ - average by the pipe section velocity of the fluid movement.

1.1.1. Heat transfer in laminar fluid flow regime in pipes $(\boldsymbol{R} \boldsymbol{e} \leq \mathbf{2 3 0 0})$. Heat pipes at a stabilized flow and stabilized heat transfer can be calculated at $T_{w}=$ const and $q_{w}=$ const by the approximate formula [9]:

$$
N_{u}=4 \varepsilon_{t},
$$

where the amendment $\varepsilon_{t}$ is calculated by the formula

$$
\varepsilon_{t}=\left(\frac{P r_{f l}}{P r_{w}}\right)^{0.25}
$$

In laminar regime of the movement in the direct smooth pipes and presence of sections of hydrodynamic and thermal stabilization for a more accurate approximation of the experimental data there are two subregimes: laminar viscous and laminar viscousgravitational. Laminar viscous flow regime occurs when Rayleigh numbers $R a<8 \cdot 10^{5}$ and laminar viscousgravitational mode when $R a \geq 8 \cdot 10^{5}$.

Heat transfer at the laminar viscous flow regime in pipes $\left(R e \leq 2300 ; R a<8 \cdot 10^{5}\right)$. Average by the internal surface of the pipe of length $l$ heat transfer coefficient is calculated by the formula obtained at $l /(R e \cdot d) \leq 0.05$ and $0.07 \leq \mu_{w} / \mu_{f} \leq 1500[5]$ :

$$
N u=1.55\left(\operatorname{Re} \cdot d_{i n} / l\right)^{1 / 3} \cdot\left(\mu_{f} / \mu_{w}\right)^{0.14} \cdot \varepsilon_{l} .
$$

The value $\varepsilon_{l}$ of amendment taking into account the impact on heat transfer of hydrodynamic flow stabilization in the initial section of heat:

- at:

$$
\frac{l}{R e \cdot d}<0.1-\varepsilon_{l}=0.6\left(\frac{l}{R e \cdot d}\right)^{-\frac{1}{7}}\left(1+2.5 \frac{l}{(\operatorname{Re} \cdot d)}\right),
$$

- at:

$$
l /(\operatorname{Re} \cdot d)<0.1-\varepsilon_{l} \approx 1 .
$$

Heat transfer at the laminar viscous-gravitational fluid medium mode in pipes ( $\left.R e \leq 2300 ; R a<8 \cdot 10^{5}\right)$. Average heat transfer coefficient at the laminar viscousgravitational medium mode can be calculated by the M.A. Mikheyev criterion equation [10]:

$$
N u=0.15 \cdot R e_{f, d}^{0.33} \cdot \operatorname{Pr}_{f}^{0.33} \cdot\left(G r_{f, d} \cdot \operatorname{Pr}_{f}\right)^{0.1} \cdot \varepsilon_{t} \cdot \varepsilon_{l} \text {. }
$$

Correction factor $\varepsilon_{l}$ taking into account the impact on heat transfer of the process of hydrodynamic flow stabilization in the initial section of heat transfer equal to:

- at $l / d<50$ values of $\varepsilon_{l}$ are founded by experimental data [6];

- at $l / d \geq 50-\varepsilon_{l}=1$.

1.1.2. Heat transfer at the turbulent fluid movement mode in pipes $\left(R e \geq 10^{4}\right)$. Average heat transfer coefficient at the turbulent fluid flow in direct smooth pipes is calculated by the M.A. Mikheyev formula [10]:

$$
N u_{f, d}=0.021 \cdot \operatorname{Re}_{f, d}^{0.8} \cdot \operatorname{Pr}_{f}^{0.43} \cdot \varepsilon_{t} \cdot \varepsilon_{l} .
$$

Correction factor $\varepsilon_{l}$ taking into account the impact on heat transfer of the process of hydrodynamic flow stabilization in the initial section of heat transfer equal to:

- at $l / d<50-\varepsilon_{l} \approx 1+2 d / l$;

- at $l / d \geq 50-\varepsilon_{l}=1$.

Values of $\varepsilon_{l}$ depending on the Reynolds criterion are presented in [9].

1.1.3. Heat transfer at the transition fluid flow regime in pipes $\left(2300<R e<10^{4}\right)$. The transitional flow regime is characterized by mixing laminar and turbulent flows. In this case, the heat transfer coefficient can be calculated by the formula [10]:

$$
N u_{f, d}=K_{0} \cdot \operatorname{Pr}_{f}^{0.43} \cdot \varepsilon_{t} \cdot \varepsilon_{l},
$$

where the complex $K_{0}$ depends on the Reynolds number [10], and the amendment $\varepsilon_{l}$ is calculated like at turbulent mode of the fluid flow.

1.2. Heat transfer at the motion of fluid in the channels of arbitrary cross-section. All of the above criterion formula for calculating heat transfer in circular pipe have been used for the calculation of heat transfer during the flow of liquids and gases in channels of other (non-circular) cross-sectional shapes (rectangular, triangular, ring, etc.), the longitudinal washing of pipes beams entered to the channel of arbitrary cross-section, and at the fluid flow that does 
not fill the entire cross-section of the channel. Here, as the characteristic size equivalent or hydraulic diameter of the channel should be used:

$$
R_{0}=d_{e k v}=d_{r}=4 f / P,
$$

where $f$ is the area of the flow cross-section, $\mathrm{m}^{2}$; $P$ is the wetted perimeter of the channel, $\mathrm{m}$.

1.3. Heat transfer at the turbulent motion of fluid in the curved pipes. At the movement of liquid in curved pipes (laps, coil) there is its additional turbulence and, consequently, increasing the heat transfer coefficient [11]. To calculate the heat transfer in the curved pipes it is necessary to multiply the Nusselt number the on correction factor:

$$
\varepsilon_{g}=1+1.8 \cdot d_{\text {in }} / R_{g}
$$

where $d_{\text {in }}$ is the internal pipe diameter, and $R_{g}$ is the bend radius.

2. Results of investigation and their discussion. As shown earlier [5] to reach acceptable temperatures of SB the intensity of the heat transfer should be increased. You can use either increase of the area of heat transfer through the use of radiator, or try to use turbulent flow of coolant to increase the heat transfer coefficient [12].

Based on the proposed theoretical study, two options for designs that are shown schematically in Fig. 1 are considered. The design shown in Fig. 1, $a$ has a large area of the heat exchanger, and the design shown in Fig. 1, $b$ has a large coefficient of heat transfer at the heat exchanger area close to the area of the heat receiving plate.
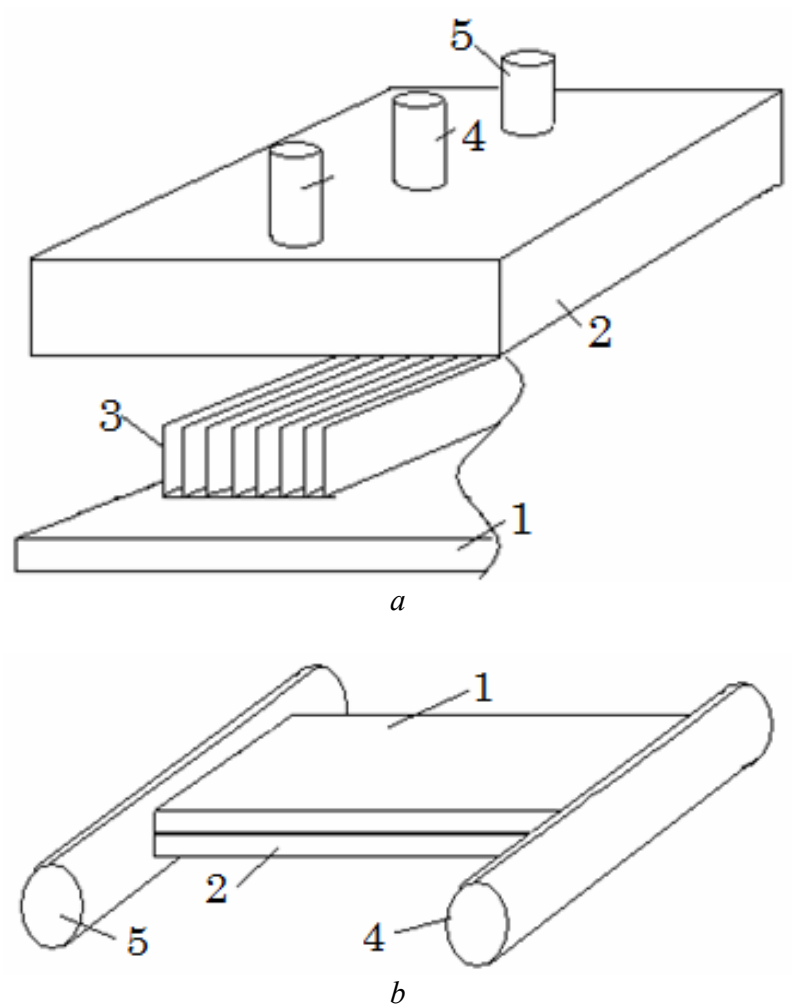

Fig. 1. Schematic representation of the designs of the cooling block with plate radiator (a) and ram with a small gap width between the plates (b): 1 - cover of the cooling block, 2 - the cooling block housing, 3 - radiator plates, 4 - tube for feeding coolant 5 - tube for cooling output
To calculate the heat exchange unit with a radiator with a large area of heat exchange surface (Fig. 1,a), and industrial copper radiator used to cool the elements of computer circuits was chosen as a model. It has the following dimensions: $91 \times 91 \times 25 \mathrm{~mm}, 56$ plates, the distance between them is $1 \mathrm{~mm}$, i.e. there are 55 channels for water leaking of the cross section $1 \times 20 \mathrm{~mm}$ (including the thickness of the upper plate of $5 \mathrm{~mm}$ ), but at the central water supply there are efficiently 110 channels. At coolant (water) consumption in the first closed loop of $10 \mathrm{l} / \mathrm{min}(0.016 \mathrm{~kg} / \mathrm{s})$ the flow velocity $(w)$ in gaps between the plates is $0.0682 \mathrm{~m} / \mathrm{s}$. At an average temperature of cooling water $\sim 50^{\circ} \mathrm{C}$ kinematic viscosity of water $v=0,55610^{-6} \mathrm{~m}^{2} / \mathrm{s}$. Taking into account the effective diameter $d_{e}=1,9 \cdot 10^{-3}$ we obtain Reynolds number $R e=w d_{e} / v=234$, corresponding to laminar flow. Calculating the Grashof (495) and Rayleigh (1752) numbers we determine that in the selected radiator with indicated coolant consumption the laminar viscous flow regime takes place. Calculation of heat transfer coefficient between the coolant and radiator plates gives $N u=1.838 \mathrm{~W} /\left(\mathrm{m}^{2} \cdot \mathrm{K}\right)$, which is insufficient for effective heat dissipation, and such a heat exchanger cannot be used in the photoenergy unit.

To calculate the heat exchange unit with radiator with a large heat transfer coefficient (Fig. 1,b) it was proposed the following dimensions of the section of the water strait $1 \times 80 \mathrm{~mm}$ with length of $60 \mathrm{~mm}$. At such sizes and water consumption as above the flow velocity in gaps between the plates is $1.875 \mathrm{~m} / \mathrm{s}$. Taking into account the effective diameter $d_{e}=1,98 \cdot 10^{-3} \mathrm{~m}$ we obtain the Reynolds number $R e=w d_{e} / v=6661$, corresponding to the transition mode of the flow leakage. Calculation of heat transfer coefficient between the coolant and the upper plate of the radiator provides $N u=13931 \mathrm{~W} /\left(\mathrm{m}^{2} \cdot \mathrm{K}\right)$. Reducing the distance between the plates to critical, in terms of viscosity, $0.5 \mathrm{~mm}$ permits to increase the flow velocity to $2.92 \mathrm{~m} / \mathrm{s}$, but with less fluid consumptopn, since hydrodynamic resistance increases and the pump can provide consumption of $7 \mathrm{l} / \mathrm{min}$ that conserves the flow in transient mode. Here $N u=18483 \mathrm{~W} /\left(\mathrm{m}^{2} \cdot \mathrm{K}\right)$.

Based on performed calculations, the basic design of the flat heat exchanger has been improved with the introduction to it of microchannels to increase the coefficient of heat transfer. Block of the heat exchanger is designed as a complete unit. Fig. 2 shows the design of the radiator, which is a skirt design. In this design collecting planes with tubes which feed (outlet) coolant, and ribs that form microchannels for coolant provided are provided. The bottom of the radiator is the basis for fixing $\mathrm{SB}$, thus decreasing the thermal resistance «surface coolant».

Taking into account the presented design and theoretical investigations the mathematical modeling of such a heat exchanger operation at different fluid velocities was conducted. The main criteria for analysis were uniform cooling surface and its temperature at the supply of the above mentioned amount of heat. The corresponding heat pattern is shown in Fig. 3. 

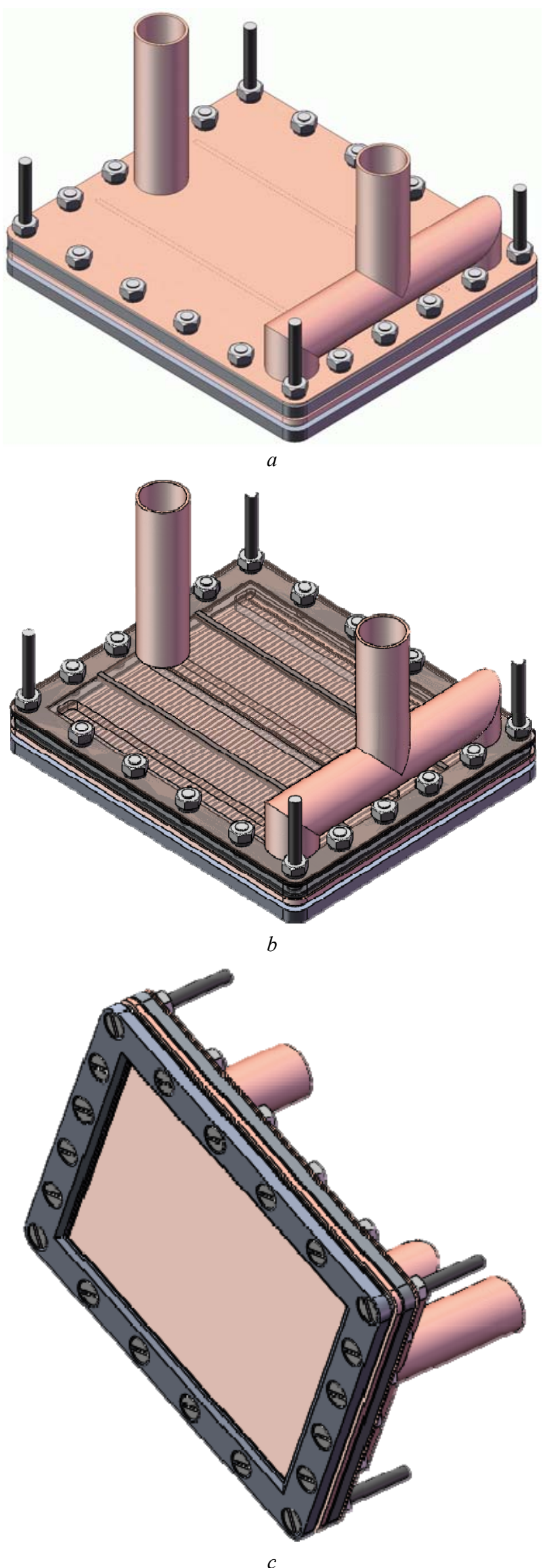

Fig. 2. Pictures of a flat heat exchanger: general $(a)$ crosssection in microchannels $(b)$ and from the heat transfer plane $(c)$
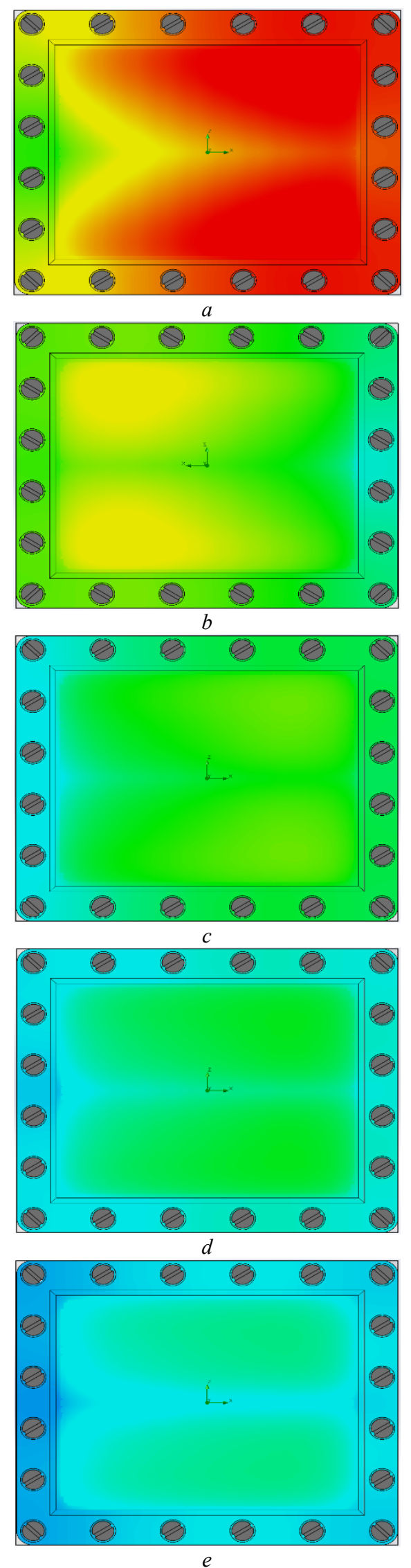

Fig. 3. Thermal patterns of the heat exchanger at following modeling conditions: $a-w=0.1 \mathrm{~m} / \mathrm{s}$, maximal surface temperature $T_{\max }=63.25^{\circ} \mathrm{C} ; b-w=0.2 \mathrm{~m} / \mathrm{s}, T_{\max }=48.27{ }^{\circ} \mathrm{C}$; $c-w=0.3 \mathrm{~m} / \mathrm{s}, T_{\max }=43.38^{\circ} \mathrm{C} ; d-w=0.5 \mathrm{~m} / \mathrm{s}$, $T_{\max }=39.18^{\circ} \mathrm{C} ; e-w=1.0 \mathrm{~m} / \mathrm{s}, T_{\max }=35.72{ }^{\circ} \mathrm{C}$ 
Analysis of the thermal patterns leads to the conclusion that even when the fluid flow velocity of 0.3 $\mathrm{m} / \mathrm{s}$ for the proposed design of the heat exchanger sufficient cooling surface uniformity is reached (Fig. 3,c). Here, the maximum temperature does not exceed $43.5^{\circ} \mathrm{C}$, that is enough for $\mathrm{SB}$ effective operation without reducing efficiency. At the same time, reduce of the speed of fluid leads to loss of uniformity of cooling and to significant increase in the surface temperature to more than $60{ }^{\circ} \mathrm{C}$ that is unacceptable.

It should also be noted that the required heat exchange parameters are achieved at the speed of $0.3 \mathrm{~m} / \mathrm{s}$, which is much less than $2.92 \mathrm{~m} / \mathrm{s}$, which were obtained for the classic flat heat exchanger. Here, further increase in the speed of the fluid does not substantially improve uniformity and reduce the temperature, but will require additional energy losses to create flow.

Reducing the effective fluid flow compared with the classic flat heat exchanger indicates higher efficiency of heat transfer. This is possible only during the transition from the transitional regime of fluid flow in a classic flat heat exchanger to the turbulent regime in the proposed design.

To confirm the mode change of fluid flow mathematical modeling of fluid flow in the channels of the heat exchanger was conducted, the pictures are shown in Fig. 4.

The analysis of fluid flow confirmed the movement in turbulent regime, which allows maximum heat transfer coefficient and consequently achieves uniformity of cooling and low temperature at minimum energy consumption to create the fluid flow.

\section{Conclusions.}

1. The theoretical calculations and modeling of heat transfer processes in converting solar energy in the manufactured heat exchange unit of the photoenergy plant are conducted, which showed that the most efficient is a plate heat exchanger equipped with the implementation in it of turbulent fluid flow, which achieves heat transfer coefficient of about $18 \mathrm{~kW} /\left(\mathrm{m}^{2} \cdot \mathrm{K}\right)$.

2 . Based on calculations an improved heat exchange unit with microchannels is developed and requirements correction to specifications of the photoenergy plant based on it is carried out.

3. Analytical verification of the heat exchanger permitted to determine that at selected parameters of the photoenergy plant, the heat exchanger unit provides stable operating temperature less $50{ }^{\circ} \mathrm{C}$ with the coolant flow velocity less than $0.3 \mathrm{~m} / \mathrm{s}$. The indicated temperature is optimal for solar battery operation at minimum energy consumption to create liquid flow.

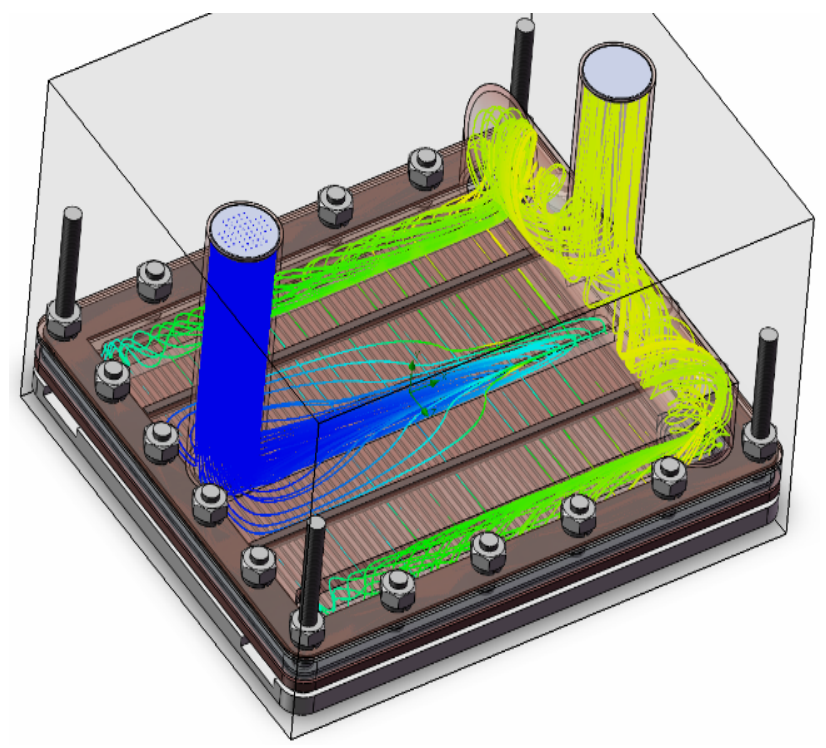

$a$

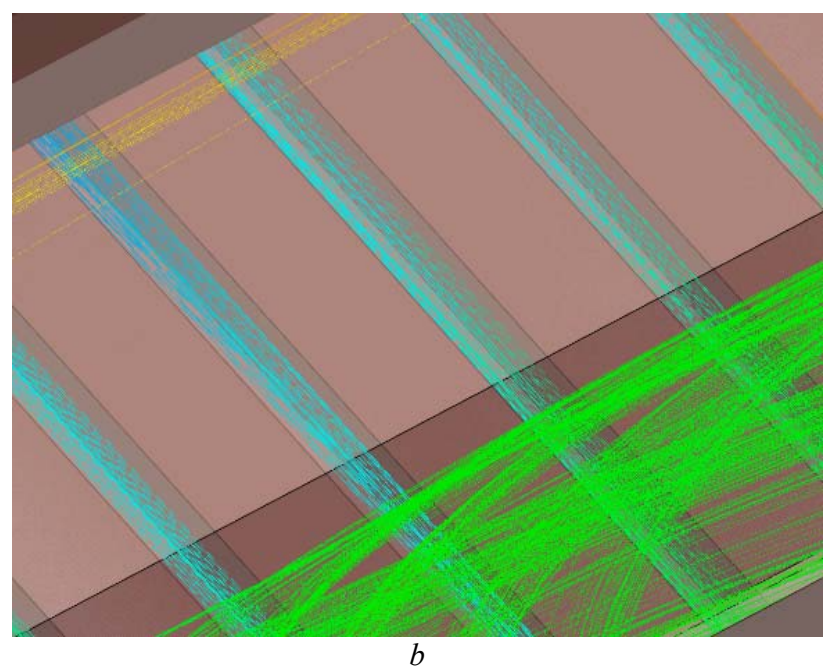

Fig. 4. Images of fluid flow modeling pictures in the heat exchanger as a whole $(a)$ and in its microchannels $(b)$

\section{REFERENCES}

1. Jones A.D., Underwood C.P. A thermal model for photovoltaic systems. Solar Energy, 2001, vol.70, iss.4, pp. 349359. doi: 10.1016/S0038-092X(00)00149-3.

2. Tuomiranta A., Marpu P., Munawwar S., Ghedira H. Validation of thermal models for photovoltaic cells under hot desert climates. Energy Procedia, 2014, vol.57, pp. 136-143. doi: 10.1016/j.egypro.2014.10.017.

3. Sokol E. Rozroblennya fotoenerhetychnoyi ustanovky na osnovi bahatoperekhidnykh kremniyevykh sonyachnykh elementiv z vertykal'nymy diodnymy komirkamy. Zvit pro NDR (zaklyuchnyy; № derzhreyestratsiyi 0111U007628) [Development of the energy picture settings based on multijunction solar cells with silicon-governmental vertical diode cells. Report on R\&D (final; state registration number 0111U007628)]. Kharkiv, NTU «KhPI», 2012. (Ukr).

4. Strebkov D.S. Matrichnye solnechnye elementy: Monografija v 3-h tomah. Tom 1 [Matrix solar cells: Monograph in 3 volumes. Vol. 1]. Moscow, GNU VIESH Publ., 2009. 120 p. (Rus).

5. Sokol E.I., Kopach V.R., Zaitsev R.V. Physical and technical features and practical limits of the photonenergy module of the new generation on the territory of Ukraine. Renewable energy, 2011, no.2(25), pp. 18-28. (Rus). 
6. Reddy K.S., Premkumar D., Vikram T.S. Heat transfer modeling and analysis of solar thermo-chemical reactor for hydrogen production from water. Energy Procedia, 2014, vol.57, pp. 570-579. doi: 10.1016/j.egypro.2014.10.211.

7. Steinfeld A. Solar thermochemical production of hydrogen a review. Solar Energy, 2005, vol.78, iss.5, pp. 603-615. doi: 10.1016/j.solener.2003.12.012.

8. Modi A., Buhler F., Andreasen J.G., Haglind F. A review of solar energy based heat and power generation systems. Renewable and Sustainable Energy Reviews, 2017, vol.67, pp. 1047-1064. doi: 10.1016/j.rser.2016.09.075.

9. Isachenko V.P., Osipov V.A., Sukomel A.S. Teploperedacha [Heat transfer]. Moscow, Enegroizdat Publ., 1981. 488 p. (Rus).

10. Mikheyev M.A. Osnovy teploperedachi [Fundamentals of heat transfer]. Moscow-Leningrad: Gosenergoizdat Publ., 1960. 208 p. (Rus).

11. Shokri R., Ghaemi S., Nobes D.S., Sanders R.S. Investigation of particle-laden turbulent pipe flow at highReynolds-number using particle image/tracking velocimetry (PIV/PTV). International Journal of Multiphase Flow, 2017, vol.89,

pp.

136-149.

doi:

10.1016/j.ijmultiphaseflow.2016.06.023.

12. Shirvan K.M., Ellahi R., Mirzakhanlari S., Mamourian M. Enhancement of heat transfer and heat exchanger effectiveness in a double pipe heat exchanger filled with porous media: Numerical simulation and sensitivity analysis of turbulent fluid flow. Applied Thermal Engineering, 2016, vol.109, Part A, pp. 761-774. doi: 10.1016/j.applthermaleng.2016.08.116.

Received 21.01.2017

R.V. Zaitsev, Candidate of Technical Science, Associate Professor,

National Technical University «Kharkiv Polytechnic Institute», 2, Kyrpychova Str., Kharkiv, 61002, Ukraine, phone +380688888246 , e-mail: zaitsev.poman@gmail.com

How to cite this article:

Zaitsev R.V. Modeling of an advanced heat exchange unit with microchannels for a combined photoenergy system. Electrical engineering \& electromechanics, 2017, no.3, pp. 57-62. doi: 10.20998/2074-272X.2017.3.08. 